\title{
PERBEDAAN PENERAPAN MODEL PEMBELAJARAN PROBLEM BASED LEARNING (PBL) DENGAN MODEL PEMBELAJARAN KOOPERATIF GROUP INVESTIGATION TERHADAP HASIL BELAJAR SISWA PADA MATA PELAJARAN SOSIOLOGI DI SMA NEGERI 14 BANDUNG
}

\author{
Sri Pujiastuti ${ }^{1}$, Elly Malihah ${ }^{2}$, dan Siti Komariah ${ }^{3}$ \\ ${ }^{1}$ SMA Pasundan 1 Cianjur \\ 2 Dosen Program Studi Pendidikan Sosiologi \\ ${ }^{3}$ Dosen Program Studi Pendidikan Sosiologi
}

\begin{abstract}
ABSTRAK
Penelitian bertujuan untuk mengetahui pengaruh perbedaan penerapan model pembelajaran terhadap peningkatan hasil belajar siswa pada mata pelajaran sosiologi. Metode yang digunakan adalah kuasi eksperimen. Hasil penelitian menunjukkan bahwa terdapat perbedaan hasil belajar pada siswa yang menggunakan model pembelajaran Problem Based Learning dengan hasil belajar siswa yang menggunakan model pembelajaran konvensional, terdapat perbedaan hasil belajar siswa yang menggunakan model pembelajaran kooperatif Group Investigation dengan hasil belajar siswa yang menggunakan model pembelajaran konvensional, dan terdapat perbedaan hasil belajar siswa yang menggunakan model pembelajaran Problem Based Learning dengan hasil belajar siswa yang menggunakan model pembelajaran kooperatif Group Investigation. Peningkatan hasil belajar terjadi pada siswa yang menggunakan model pembelajaran Problem Based Learning.
\end{abstract}

Kata kunci: model pembelajaran Problem Based Learning (PBL), model pembelajaran kooperatif Group Investigation (Gl), hasil belajar siswa. 
PENDAHULUAN

Pendidikan memiliki peranan penting dalam meningkatkan kualitas sumber daya manusia serta upaya untuk mewujudkan cita-cita bangsa Indonesia dalam mewujudkan kesejahteraan umum serta mencerdaskan kehidupan bangsa.

Permasalahan yang timbul adalah pendidikan kita masih didominasi oleh pandangan bahwa pengetahuan sebagai perangkat fakta-fakta yang harus dihafal, termasuk dalam mata pelajaran sosiologi..

SMA Negeri 14 Bandung merupakan salah satu sekolah yang belum pernah menggunakan model pembelajaran Problem Based Learning (PBL) dan model pembelajaran kooperatif Group Investigation (Gl), khususnya pada mata pelajaran sosiologi. Model pembelajaran yang digunakan oleh guru sosiologi di SMA Negeri 14 Bandung adalah model konvesional ceramah bervariasi, seperti tanya jawab ataupun diskusi. Hal ini dibuktikan dengan jumlah siswa IPS kelas XI yang mencapai nilai KKM adalah sebanyak $70 \%$. Nilai KKM pada mata pelajaran sosiologi di SMA Negeri 14 Bandung kelas XI adalah 78. Oleh sebab itu masih terdapat $30 \%$ siswa yang mengalami kesulitan dalam mempelajari mata pelajaran sosiologi.

Salah satu upaya peningkatan kualitas pembelajaran di sekolah yaitu dengan memperhatikan metode pembelajaran yang diterapkan di sekolah.

\section{HASIL PENELITIAN}

Data hasil belajar di SMA Negeri 14 Bandung dengan menggunakan model pembelajaran Problem Based
Learning dan model pembelajaran kooperatif Group Investigation didapat dari tes awal (pretest), kemudian diberikan treatment, tes akhir (post test) hasil dari peningkatan belajar setelah diberikan treatment. Hasil pengolahan data ini meliputi perhitungan rata-rata, simpangan baku dan variansi menggunakan data mentah.

Tabel 1

Hasil Perhitungan Skor Rata-rata dan Simpangan Baku

Kelompok Eksperimen dan Kelompok Kontrol

\begin{tabular}{|c|c|c|}
\hline No & $\begin{array}{c}\text { Kelompo } \\
\mathbf{k}\end{array}$ & $\begin{array}{c}\text { Rata- } \\
\text { rata } \\
(\bar{x})\end{array}$ \\
\hline
\end{tabular}

\begin{tabular}{cccc}
\hline 1 & $\begin{array}{c}\text { Eksperim } \\
\text { en } 1\end{array}$ & 21,18 & 2,43 \\
\hline 2 & $\begin{array}{c}\text { Eksperim } \\
\text { en2 }\end{array}$ & 20,55 & 2,04 \\
\hline 3 & Kontrol & 21,66 & 2,35 \\
\hline
\end{tabular}

Setelah diketahui nilai rata-rata dan simpangan baku dari kelompok eksperimen ${ }_{1}$ eksperimen, ${ }_{2}$ dan kelompok kontrol, selanjutnya penulis menganalisis data dengan menghitung uji normalitas data dengan uji chi kuadrat, dan uji homogenitas dengan uji Bartlett. Hasil perhitungan uji normalitas dapat dilihat pada tabel berikut:

Tabel 2

Hasil Pengujian Uji Normalitas Chi Kuadrat Dari Kelompok Eksperimen Dengan Model Pembelajaran Problem Based Learning

\begin{tabular}{cccccc}
\hline $\mathbf{N}$ & Test & $\mathbf{N}$ & $\begin{array}{c}\boldsymbol{X}^{2} \\
\text { hitung }\end{array}$ & $\boldsymbol{X}^{2}$ tabel & $\begin{array}{c}\text { Hasil } \\
\mathbf{U j i}\end{array}$ \\
\hline 1 & Pre & 3 & 2,54 & $\begin{array}{c}11,07 \\
0\end{array}$ & Normal \\
& test & 8 & & 0 & \\
\hline
\end{tabular}




\begin{tabular}{cccccc}
\hline 2 & $\begin{array}{c}\text { Post } \\
\text { test }\end{array}$ & 8 & 1,866 & 12,59 & Normal \\
& tes & & 2 & \\
\hline
\end{tabular}

Berdasarkan tabel 2, dapat diketahui bahwa nilai $X^{2}$ tabel tes awal dalam taraf nyata 0,05 dengan $\mathrm{dk}=6-1$ $=11,070$ dan $\mathrm{X}^{2}$ tabel tes akhir dalam taraf nyata 0,05 dengan $\mathrm{dk}=7-1=12,592$, sedangkan dari hasil perhitungan diperoleh $\mathrm{X}^{2}$ hitung tes awal dan tes akhir pada kelompok pembelajaran dengan menggunakan Problem Based Learning adalah 2,54 dan 1,866. Kriteria pengujiannya adalah tolak $\mathrm{H}_{0}$ jika $\mathrm{X}^{2}$ hitung yang diperoleh dari data pengamatan lebih besar dari $\mathrm{x}^{2}$ tabel selain dari itu maka $\mathrm{H}_{0}$ diterima. Dengan demikian data tes awal dan tes akhir dengan menggunakan model pembelajaran Problem Based Learning berdistribusi normal, karena nilai $\mathrm{X}^{2}$ hitung lebih kecil dari nilai $\mathrm{X}^{2}$ tabel.

Tabel 3

Hasil Pengujian Uji Normalitas Chi Kuadrat Dari Kelompok Eksperimen2 Dengan Model Pembelajaran Kooperatif Group Investigation

\begin{tabular}{cccccc}
\hline $\mathbf{N}$ & Test & $\mathbf{N}$ & $\begin{array}{c}\boldsymbol{X}^{2} \\
\text { hitung }\end{array}$ & $\begin{array}{c}\boldsymbol{X}^{2} \text { tab } \\
\text { el }\end{array}$ & $\begin{array}{c}\text { Hasil } \\
\text { Uji }\end{array}$ \\
\hline 1 & Pre & 3 & 6,612 & 15,50 & Norm \\
& test & 8 & 3 & 7 & al \\
\hline 2 & Post & 3 & 1,194 & 9,488 & Norm \\
& test & 8 & 0 & & al \\
\hline
\end{tabular}

Berdasarkan tabel 3, dapat diketahui bahwa nilai $X^{2}$ tabel tes awal dalam taraf nyata 0,05 dengan $\mathrm{dk}=9-1$ $=15,507$ dan $X^{2}$ tabel tes akhir dalam taraf nyata 0,05 dengan $\mathrm{dk}=5-1=9,488$, sedangkan dari hasil perhitungan diperoleh $\mathrm{X}^{2}$ hitung tes awal dan tes akhir pada kelompok pembelajaran dengan menggunakan model pembelajaran kooperatif Group Investigation adalah 6,6123 dan 1,1940. Kriteria pengujiannya adalah tolak $\mathrm{H}_{0}$ jika $\mathrm{X}^{2}$ hitung yang diperoleh dari data pengamatan lebih besar dari $X^{2}$ tabel, selain dari itu maka $\mathrm{H}_{0}$ diterima. Dengan demikian data tes awal dan tes akhir dengan menggunakan model pembelajaran kooperatif Group Investigation berdistribusi normal, karena nilai $\mathrm{X}^{2}$ hitung lebih kecil dari nilai $\mathrm{X}^{2}$ tabel.

Tabel 4

Hasil Pengujian Uji Normalitas Chi Kuadrat Dari Kelompok Kontrol

\begin{tabular}{cccccc}
\hline $\mathbf{N}$ & Test & $\mathbf{N}$ & $\begin{array}{c}\boldsymbol{X}^{2} \\
\text { o }\end{array}$ & $\boldsymbol{X}^{2}$ tabel & $\begin{array}{c}\text { Hasil } \\
\mathbf{U j i}\end{array}$ \\
\hline 1 & Pre & 3 & 2,373 & $\begin{array}{c}11,07 \\
0\end{array}$ & Norm \\
& test & 8 & & al \\
\hline 2 & $\begin{array}{c}\text { Post } \\
\text { test }\end{array}$ & 8 & 4,092 & $\begin{array}{c}11,07 \\
0\end{array}$ & Norm \\
& tes \\
\hline
\end{tabular}

Berdasarkan tabel 4, dapat diketahui bahwa nilai $\mathrm{X}^{2}$ tabel tes awal dalam taraf nyata 0,05 dengan $\mathrm{dk}=6-1$ $=11,070$ dan $\mathrm{X}_{\text {tabel }}^{2}$ tes akhir dalam taraf nyata 0,05 dengan $\mathrm{dk}=6-1=$ 11,070 , sedangkan dari hasil perhitungan diperoleh $X^{2}$ hitung tes awal dan tes akhir pada kelompok pembelajaran dengan model pembelajaran konvensional adalah 2,373 dan 4,092 . Kriteria pengujiannya adalah tolak $\mathrm{H}_{0}$ jika $X^{2}{ }_{\text {hitung }}$ yang diperoleh dari data pengamatan lebih besar dari $\mathrm{X}^{2}$ tabel, selain dari itu maka $\mathrm{H}_{0}$ diterima. Dengan demikian data tes awal dan tes akhir dengan menggunakan model pembelajaran konvensional berdistribusi normal, 
karena nilai $X^{2}$ hitung lebih kecil dari nilai $\mathrm{X}^{2}$ tabel.

Langkah selanjutnya adalah melakukan pengujian homogenitas dengan menggunakan uji Bartlett dengan pendekatan Chi Kuadrat. Hasil pengujian dari data penelitian disajikan dalam tabel 5.

\section{Tabel 5}

Hasil Pengujian Homogenitas (Kesamaan Beberapa Varians) dari Kelompok Eksperimen dan Kelompok Kontrol

\begin{tabular}{|c|c|c|c|c|c|}
\hline $\begin{array}{l}\mathbf{N} \\
\mathbf{O}\end{array}$ & $\begin{array}{c}\text { Kelompo } \\
\mathbf{k}\end{array}$ & $\begin{array}{c}\text { Varia } \\
\text { nsi }\end{array}$ & $\begin{array}{c}X^{2} \text { hitu } \\
\text { ng }\end{array}$ & $\begin{array}{l}\mathrm{X}^{2}{ }_{\mathrm{ta}} \\
\text { bel }\end{array}$ & $\begin{array}{c}\text { Hasil } \\
\text { Uji }\end{array}$ \\
\hline 1 & $\begin{array}{c}\text { Eksperim } \\
\text { en } 1\end{array}$ & 6,0 & \multirow{3}{*}{2,63} & \multirow{3}{*}{1,71} & \multirow{3}{*}{$\begin{array}{c}\text { Homog } \\
\text { en }\end{array}$} \\
\hline 2 & $\begin{array}{c}\text { Eksperim } \\
\text { en2 }\end{array}$ & 4,6 & & & \\
\hline 3 & Kontrol & 6,3 & & & \\
\hline
\end{tabular}

Kriteria pengujian homogenitas adalah batas kritis penerimaan atau penolakan hipotesis, dengan derajat kebebasan pembilang ( $\mathrm{k}-1)$ dan derajat kebebasan penyebut $(\mathrm{k}-1)$ dengan taraf kesalahan $5 \%$ dan derajat kebebasan penyebut $\mathrm{k}-1=3-1=2$ atau nilai $\mathrm{X}^{2}$ tabel $=$ 1,71. Jika $X^{2}$ hitung $>X^{2}$ tabel maka data tersebut berdistribusi homogen.

Berdasarkan hasil pengujian kesamaan beberapa varians kelompok eksperimen, kelompok eksperimen dan kelompok kontrol maka dapat diketahui bahwa hasil $X^{2}$ hitung adalah 2,63 dan $X^{2}$ tabel adalah 1,71. Dengan demikian $X^{2}$ hitung $2,63>X^{2}$ tabel 1,71 . Maka dapat disimpulkan bahwa data berdistribusi homogen.
Setelah hasil pengujian homogenitas menunjukkan data yang homogen dan hasil uji normalitas menunjukkan data yang terdistribusi normal, maka langkah selanjutnya adalah melakukan pengujian perbedaan signifikansi dengan menggunakan pengujian dua pihak atau dua rata-rata peningkatan hasil belajar kelompok eksperimen 1 dan kelompok eksperimen dengan menggunakan uji signifikansi dua pihak atau dua rata-rata yaitu uji-t. Hasil pengujian kesamaan dua rata-rata peningkatan hasil belajar siswa pada mata pelajaran sosiologi disajikan pada tabel 6.

\section{Tabel 6}

Hasil Perhitungan Uji Signifikansi

Peningkatan Hasil Pembelajaran dari Kelompok Eksperimen 1 dan

Kelompok Eksperimen2

\begin{tabular}{|c|c|c|c|c|c|c|}
\hline $\mathbf{N}$ & $\begin{array}{c}\text { Kelo } \\
\text { mpo } \\
\text { k }\end{array}$ & $\bar{X}$ & $\begin{array}{c}\text { Vari } \\
\text { ansi } \\
\text { (S) }\end{array}$ & $\begin{array}{l}\text { Thit } \\
\text { ung }\end{array}$ & $\begin{array}{l}T_{\text {ta }} \\
\text { bel }\end{array}$ & $\begin{array}{c}\text { Signi } \\
\text { fikan } \\
\text { si }\end{array}$ \\
\hline & Eksp & 21 & & \multirow{6}{*}{$\begin{array}{c}2,2 \\
5\end{array}$} & \multirow{6}{*}{$\begin{array}{l}1, \\
99\end{array}$} & \multirow{6}{*}{$\begin{array}{l}\text { Signi } \\
\text { ikan }\end{array}$} \\
\hline 1 & erim & , 1 & 1,15 & & & \\
\hline & en $_{1}$ & 8 & & & & \\
\hline \multirow{3}{*}{2} & Eksp & 20 & & & & \\
\hline & erim & ,5 & 1,84 & & & \\
\hline & en2 & 5 & & & & \\
\hline
\end{tabular}

Berdasarkan hasil perhitungan uji signifikansi, peningkatan hasil belajar siswa dengan menggunakan model pembelajaran Problem Based Learning dan model pembelajaran kooperatif Group Investigation disajikan pada Tabel 6 yang diperoleh data rata-rata selisih peningkatan pada kelompok eksperimen ${ }_{1}$ adalah 21,18 sedangkan pada kelompok eksperimen, adalah 20,55. Setelah memperoleh hasil 
perhitungan rata-rata selisih peningkatan dua model pembelajaran kemudian diperoleh variansi $i_{1}$ adalah 1,15 dan variansi2 adalah 1,84. Dari hasil pengujian data-data tersebut diperoleh thitung 2,25 sedangkan nilai ttabel pada taraf kepercayaan $\alpha=0,05$ dan derajat kebebasan $\mathrm{dk}=38+38-2=$ 74 , harga $t_{1-0,05}(0,95)$ dari daftar distribusi t diperoleh 1,99. Oleh karena itu,maka kriteria pengujian adalah tolak $\mathrm{H}_{0}$ jika thitung $>$ ttabel 1- $\alpha$. Hasil perhitungan menunjukkan bahwa thitung $(2,25)>$ tabel $(1,99)$. Karena thitung berada pada daerah penolakan, maka $\mathrm{H}_{0}$ ditolak. Hal ini berarti terdapat perbedaan hasil belajar siswa yang menggunakan model pembelajaran Problem Based Learning dengan hasil belajar siswa yang menggunakan model pembelajaran kooperatif Group Investigation pada mata pelajaran sosiologi di SMA Negeri 14 Bandung.

\section{PEMBAHASAN PENELITIAN}

Salah satu model pembelajaran yang dapat dikembangkan dan diadopsi untuk menempatkan siswa sebagai pusat pembelajaran adalah penerapan model Problem Based Learning (PBL) (Gunantara, dkk, 2014, hlm. 2).

Kelas XI IPS 1 SMA Negeri 14 Bandung merupakan kelas yang dipilih sebagai kelas yang diberikan perlakuan dengan menggunakan model pembelajaran Problem Based Learning (PBL). Tes yang diberikan adalah pre test sebagai alat ukur untuk mengetahui kemampuan awal siswa sebelum diberikan perlakuan dengan model pembelajaran Problem Based Learning dan post test diberikan setelah mendapatkan perlakuan dengan model pembelajaran Problem Based Learning.
Soal yang diberikan adalah tes tulis dengan jumlah 30 butir soal pilihan ganda dengan pokok bahasan kelompok sosial.

Berdasarkan hasil penelitian yang telah dilakukan, siswa di kelas XI IPS 1 SMA Negeri 14 Bandung yang menggunakan model pembelajaran Problem Based Learning mengalami peningkatan hasil belajar pada mata pelajaran sosiologi. Hal ini dapat dilihat dari hasil pre test dan post test siswa di mana nilai yang diperoleh siswa mengalami peningkatan. Dengan adanya peningkatan hasil belajar siswa di kelas XI IPS 1 dapat menunjukkan bahwa model pembelajaran Problem Based Learning cukup tepat dan efektif untuk diterapkan pada mata pelajaran sosiologi khususnya pada materi kelompok sosial, karena selain dapat meningkatkan hasil belajar siswa, model pembelajaran Problem Based Learning dapat melatih siswa untuk belajar lebih mandiri dan kritis. Hal ini sejalan dengan pendapat Sudjana (dalam Adawiyah, R, 2011, hlm. 11) bahwa manfaat khusus yang diperoleh dari metode Dewey adalah metode pemecahan masalah. Tugas guru adalah membantu para siswa merumuskan tugas-tugas, dan bukan menyajikan tugas-tugas pelajaran. Objek pelajaran tidak dipelajari dari buku, tetapi dari masalah yang ada di sekitarnya.

Kelas XI IPS 3 SMA Negeri 14 Bandung merupakan kelas yang dipilih sebagai kelas yang diberikan perlakuan dengan menggunakan model pembelajaran kooperatif Group Investigation (GI). Menurut Sudjana (dalam Anita, dkk., 2013, hlm. 3) model pembelajaran investigasi kelompok 
memiliki tiga konsep utama yaitu penyelidikan (inquiry), pengetahuan (knowladge), dan dinamika kelompok belajar (dinamic of learning group). Cara untuk mengetahui peningkatan hasil belajar siswa pada kelas XI IPS 3 adalah dengan menggunakan tes sebagai alat ukurnya. Tes yang diberikan adalah pre test sebagai alat ukur untuk mengetahui kemampuan awal siswa sebelum diberikan perlakuan dengan model pembelajaran kooperatif Group Investigation (GI) dan post test diberikan setelah mendapatkan perlakuan dengan model pembelajaran kooperatif Group Investigation (GI). Soal yang diberikan adalah tes tulis dengan jumlah 30 butir soal pilihan ganda dengan pokok bahasan kelompok sosial.

Berdasarkan hasil penelitian yang telah dilakukan, siswa di kelas XI IPS 3 SMA Negeri 14 Bandung yang menggunakan model pembelajaran kooperatif Group Investigation (Gl) tidak mengalami peningkatan hasil belajar pada mata pelajaran sosiologi. Hal ini dapat dilihat dari hasil pre test dan post test siswa. Dengan tidak adanya peningkatan hasil belajar siswa di kelas XI IPS 3 dapat menunjukkan bahwa model pembelajaran kooperatif Group Investigation (Gl) masih kurang efektif untuk diterapkan pada mata pelajaran sosiologi. Hal ini dapat terjadi karena kurangnya kesiapan siswa untuk mengikuti mata pelajaran sosiologi dengan menggunakan model pembelajaran yang berbeda dari biasanya. Tidak hanya itu saja, penyebab lain yang membuat siswa di kelas XI IPS 3 tidak mengalami peningkatan hasil belajar disebabkan oleh waktu belajar mata pelajaran sosiologi yang kurang tepat, yaitu pada siang hari, sehingga menyebabkan siswa kurang konsentrasi pada saat mengikuti kegiatan belajar.

Kelas XI IPS 2 SMA Negeri 14 Bandung merupakan kelas yang dipilih sebagai kelas yang diberikan perlakuan dengan menggunakan model pembelajaran konvensional dengan metode ceramah. Cara untuk mengetahui peningkatan hasil belajar siswa pada kelas XI IPS 2 adalah dengan menggunakan tes sebagai alat ukurnya. Tes yang diberikan adalah pre test sebagai alat ukur untuk mengetahui kemampuan awal siswa sebelum diberikan perlakuan dengan model pembelajaran konvensional dan post test diberikan setelah mendapatkan perlakuan dengan model pembelajaran konvensional. Soal yang diberikan adalah tes tulis dengan jumlah 30 butir soal pilihan ganda dengan pokok bahasan kelompok sosial.

Berdasarkan hasil penelitian yang telah dilakukan, siswa di kelas XI IPS 2 SMA Negeri 14 Bandung yang menggunakan model pembelajaran konvensional dengan metode ceramah tidak mengalami peningkatan hasil belajar pada mata pelajaran sosiologi. Hal ini dapat dilihat dari hasil pre test dan post test siswa. Dengan tidak adanya peningkatan hasil belajar siswa di kelas XI IPS 2 dapat menunjukkan bahwa model pembelajaran model pembelajaran konvensional dengan metode ceramah masih kurang efektif untuk diterapkan pada mata pelajaran sosiologi. Model pembelajaran konvensional dengan metode ceramah memang kurang memunculkan keaktifan siswa pada saat kegiatan pembelajaran berlangsung. Siswa yang kurang 
memiliki ketertarikan terhadap mata pelajaran sosiologi akan senantiasa menganggap mata pelajaran sosiologi merupakan salah satu mata pelajaran yang membosankan. Tidak adanya peningkatan hasil belajar siswa di kelas XI IPS 2 bukan hanya disebabkan oleh penerapan model pembelajaran konvensional ceramah saja namun juga disebabkan oleh waktu belajar mata pelajaran sosiologi yang kurang tepat, yaitu pada siang hari, sehingga menyebabkan siswa kurang konsentrasi pada saat mengikuti kegiatan belajar.

Selain tes, hasil belajar diperoleh melalui lembar observasi yang telah disesuaikan dengan proses kegiatan belajar dengan menggunakan model pembelajaran Problem Based Learning (PBL) dan model pembelajaran Group Investigation (GI). Berdasarkan pendapat Dimyati, dkk, (dalam Wulandari dan Surjono, 2013, hlm. 183) menyatakan bahwa hasil belajar adalah ukuran atau tingkat keberhasilan yang dapat dicapai oleh seorang siswa berdasarkan pengalaman yang diperoleh setelah dilakukan evaluasi berupa tes dan biasanya diwujudkan melalui angka-angka tertentu serta menyebabkan terjadinya perubahan kognitif, afektif, maupun psikomotorik. Observasi dilakukan oleh peneliti untuk melihat dan mengamati aktivitas siswa selama mengikuti kegiatan belajar sosiologi di kelas. Kawasan kognitif, afektif, dan psikomotorik sebagai hasil belajar diformulasikan oleh Bloom dan kawan-kawan (dalam Wulandari dan Surjono, 2013, hlm. 183) di mana setiap aspek mempunyai tujuan kependidikan. Kawasan kognitif mencakup tujuan kependidikan yang berhubungan dengan pengingatan atau pengenalan tentang pengetahuan dan pengembangan keterampilan, dan kemampuan intelektual. Kawasan afektif mencakup tujuan kependidikan yang mendeskripsikan perubahan dalam ketertarikan, sikap, nilai, serta pengembangan apresiasi. Kawasan psikomotorik meliputi hasil belajar yang berkaitan dengan manipulasi dan keterampilan gerak anggota badan.

Kelas XI IPS 1 SMA Negeri 14 Bandung merupakan kelas yang diberikan perlakuan dengan menggunakan model pembelajaran Problem Based Learning (PBL). Pada pertemuan pertama, peneliti memberikan tes awal (pre test) kepada siswa kelas XI IPS 1 dengan jumlah 30 soal pilihan ganda. Materi yang diujikan kepada siswa yaitu tentang kelompok sosial. Jumlah siswa yang mengikuti pre test adalah 38 orang siswa. Waktu untuk mengerjakan soal berlangsung selama 45 menit. Seluruh siswa dapat dikondisikan dengan baik karena siswa dapat mengerjakan pre test dengan tenang. Dengan kondisi kelas yang tenang, seluruh siswa dapat berkonsentrasi dalam menjawab soalsoal yang telah disediakan. Mereka mengumpulkan kertas jawaban tepat pada waktu yang telah ditentukan. Selesai mengerjakan pre test, peneliti mulai memancing siswa untuk ikut aktif dalam pembelajaran dengan cara menanyakan apa saja yang mereka ketahui tentang kelompok sosial. Siswa terlihat antusias untuk memberikan argumen. Selanjutnya, peneliti mulai memberikan materi dengan menggunakan model pembelajaran Problem Based Learning (PBL). Peneliti membagi siswa menjadi beberapa kelompok heterogen yang terdiri dari 6-7 
orang siswa. Setelah seluruh siswa sudah mendapatkan kelompok, siswa kembali duduk bersama teman-teman sekelompoknya. Peneliti mulai membagikan artikel yang berhubungan dengan masalah-masalah kelompok sosial yang terjadi di Indonesia kepada siswa. Siswa mendengarkan setiap arahan yang disampaikan oleh peneliti.

Pada pertemuan selanjutnya siswa ditugaskan untuk mendiskusikan artikel yang telah didapatkan pada pertemuan sebelumnya bersama teman-teman sekelompoknya. Peneliti menugaskan siswa untuk mencari data dengan melakukan wawancara agar siswa dapat terjun langsung berinteraksi dengan masyarakat. Selain itu, siswa juga ditugaskan untuk mencari data atau informasi dari berbagai sumber yang mendukung pemecahan masalah pada artikel tersebut. Setiap ketua kelompok diharuskan untuk membagi tugas kepada masing-masing anggota kelompoknya. Seluruh siswa ikut terlibat saat proses diskusi berlangsung. Pada tahap-tahap selanjutnya peneliti bertugas memantau perkembangan siswa selama mengumpulkan data. Setelah seluruh kelompok berhasil mengumpulkan data dan informasi yang dibutuhkan, siswa ditugaskan untuk membuat laporan dan mempresentasikan hasil temuannya. Siswa yang melakukan presentasi sudah cukup baik dalam menyampaikan hasil laporannya, sedangkan siswa yang menjadi audience begitu antusias memperhatikan siswa yang sedang melakukan presentasi. Selain itu, siswa juga ikut berpartisipasi aktif dalam bertanya dan menyampaikan argumen. Pada akhir pembelajaran peneliti mengevaluasi dengan memberikan kesempatan kepada siswa untuk menanyakan materi yang tidak dimengerti, serta meluruskan jawabanjawaban siswa yang dianggap kurang tepat. Pada tahap selanjutnya siswa diberikan post test untuk melihat perkembangan hasil belajar siswa selama diberikan perlakuan dengan model pembelajaran Problem Based Learning (PBL). Post test yang diberikan berjumlah 30 soal pilihan ganda dengan materi kelompok sosial. Seluruh siswa mengerjakan soal dengan tenang.

Berdasarkan hasil observasi, aktivitas kelas XI IPS 1 sebagai kelas eksperimen 1 dapat mengikuti arahanarahan yang disampaikan oleh peneliti. Siswa juga begitu antusias saat proses pembelajaran dengan model Problem Based Learning berlangsung. Seluruh aktivitas kelas dapat dikondisikan dengan baik.

Kelas XI IPS 3 SMA Negeri 14 Bandung merupakan kelas yang ditetapkan sebagai kelas eksperimen 2 yang mendapatkan perlakuan dengan model pembelajaran kooperatif Group Investigation (Gl). Menurut Robert Slavin (dalam Adinata, F, 2013, hlm 5) langkah-langkahnya penerapan model pembelajaran group investigation yaitu: (1) Mengidentifikasi topik dan mengatur murid dalam kelompok, Merencanakan tugas yang akan dipelajari, (3) Melaksanakan investigasi, (4) Menyiapkan laporan akhir, (5) Mempresentasikan laporan akhir, (6) Evaluasi. Pada pertemuan pertama, peneliti memberikan tes awal (pre test) kepada siswa kelas XI IPS 3 dengan jumlah 30 soal pilihan ganda. Materi yang diujikan kepada siswa yaitu tentang kelompok sosial. Jumlah siswa yang mengikuti pre test adalah 38 orang 
siswa. Waktu untuk mengerjakan soal berlangsung selama 45 menit. Seluruh siswa dapat dikondisikan dengan baik karena siswa dapat mengerjakan pre test dengan tenang. Dengan kondisi kelas yang tenang, seluruh siswa dapat berkonsentrasi dalam menjawab soalsoal yang telah disediakan. Mereka mengumpulkan kertas jawaban tepat pada waktu yang telah ditentukan. Selesai mengerjakan pre test, peneliti mulai memancing siswa untuk ikut aktif dalam pembelajaran dengan cara menanyakan apa saja yang mereka ketahui tentang kelompok sosial. Dari keselurahan siswa yang ada, hanya terdapat beberapa siswa saja yang cukup antusias untuk memberikan argumennya. Selanjutnya, peneliti mulai memberikan materi dengan menggunakan model pembelajaran kooperatif Group Investigation (GI). Peneliti memberikan salah satu contoh masalah kelompok sosial yang terjadi di Indonesia. Selanjutnya peneliti membagi siswa menjadi beberapa kelompok heterogen yang terdiri dari 6-7 orang siswa. Pada pembagian kelompok ini siswa sulit dikondisikan, karena kebanyakan dari mereka tidak ingin satu kelompok dengan siswa yang telah dipilih, namun setelah peneliti memberikan arahan, akhirnya peneliti dapat mengkondisikan kelas kembali.

Pada pertemuan selanjutnya peneliti mengarahkan siswa untuk duduk sesuai dengan kelompoknya. Lalu, peneliti menugaskan setiap kelompok untuk mencari artikel mengenai masalah-masalah yang berhubungan dengan kelompok sosial. Setiap ketua kelompok diberikan tugas untuk membagi tugas kepada setiap anggota kelompoknya masing-masing.
Pada tahap berikutnya siswa ditugaskan untuk mendiskusikan artikel yang telah didapatkannya dan mencari penyelesaian masalah dengan melakukan investigasi. Kondisi kelas pada saat siswa berdiskusi dirasakan gaduh, sehingga kegiatan belajar kurang kondusif. Terlihat juga beberapa siswa yang tidak ikut terlibat dalam diskusi bersama teman sekelompoknya. Peneliti sudah mencoba menegurnya, namun karena waktu belajar yang sudah cukup siang membuat siswa menjadi kelelahan dan berakibat pada kurangnya konsentrasi siswa dalam mengikuti pelajaran. Lalu, peneliti menugaskan siswa untuk menuangkan seluruh hasil temuannya dalam bentuk laporan dan setiap kelompok diharuskan untuk mempresentasikan hasil laporannya masing-masing.

Pada pertemuan selanjutnya, siswa mempresentasikan hasil laporannya. Siswa yang presentasi sudah cukup baik dalam menyampaikan hasil laporannya, sedangkan siswa yang menjadi audience tidak begitu antusias dalam memperhatikan siswa yang sedang melakukan presentasi. Namun suasana kelas pada saat presentasi sudah cukup tenang. Walaupun hanya ada beberapa siswa saja yang aktif dan serius memperhatikan kelompok yang sedang presentasi, siswa lainnya menghargai temannya yang sedang presentasi dengan tidak membuat keributan di dalam kelas. Pada akhir pembelajaran peneliti mengevaluasi dengan memberikan kesempatan kepada siswa untuk menanyakan materi yang tidak dimengerti, serta meluruskan jawaban-jawaban siswa yang dianggap kurang tepat. Pertemuan selanjutnya siswa diberikan post test yang bertujuan 
untuk melihat hasil belajar siswa setelah diberikan perlakuan dengan model pembelajaran Group Investigation (Gl). Post test yang diberikan berjumlah 30 soal pilihan ganda dengan materi kelompok sosial. Seluruh siswa mengerjakan soal dengan tenang dan mengumpulkan lembar jawaban tepat pada waktunya.

Berdasarkan hasil observasi, aktivitas siswa di kelas XI IPS 3 sebagai kelas eksperimen 2 tidak begitu antusias, dikarenakan banyak kendala yang memicu keributan di dalam kelas saat proses pembelajaran dengan model kooperatif Group Investigation berlangsung. Namun siswa sudah cukup baik mengikuti arahan-arahan yang disampaikan oleh peneliti.

Kelas XI IPS 2 SMA Negeri 14 Bandung merupakan kelas yang ditetapkan sebagai kelas kontrol yang mendapatkan perlakuan dengan model pembelajaran kooperatif Group Investigation (Gl). Pada pertemuan pertama, peneliti memberikan tes awal (pre test) kepada siswa kelas XI IPS 2 dengan jumlah 30 soal pilihan ganda. Materi yang diujikan kepada siswa yaitu tentang kelompok sosial. Jumlah siswa yang mengikuti pre test adalah 38 orang siswa. Waktu untuk mengerjakan soal berlangsung selama 45 menit. Seluruh siswa dapat dikondisikan dengan baik karena siswa dapat mengerjakan pre test dengan tenang. Dengan kondisi kelas yang tenang, seluruh siswa dapat berkonsentrasi dalam menjawab soalsoal yang telah disediakan. Mereka mengumpulkan kertas jawaban tepat pada waktu yang telah ditentukan.

Pada pertemuan selanjutnya, peneliti memberikan materi kelompok sosial dengan menggunakan model pembelajaran konvensional dengan metode ceramah. Terdapat beberapa siswa yang membuat keributan di dalam kelas, namun peneliti dapat mengkondisikan siswa yang membuat keributan di dalam kelas sehingga kegiatan belajar kembali kondusif. Siswa dapat mengikuti setiap arahan yang diberikan oleh peneliti. Selanjutnya peneliti memberikan kesempatan kepada siswa untuk menanyakan materi kelompok sosial yang belum mereka pahami dan memberikan kesempatan pula kepada siswa yang ingin menjawab pertanyaan dari temannya. Dalam hal ini, hanya ada beberapa siswa saja yang bertanya. Setelah itu peneliti dan siswa sama-sama membuat kesimpulan mengenai materi yang telah disampaikan sebelumnya. Pada tahap akhir siswa diberikan post test yang bertujuan untuk melihat hasil belajar siswa setelah diberikan perlakuan dengan model pembelajaran konvensional. Post test yang diberikan berjumlah 30 soal pilihan ganda dengan materi kelompok sosial. Seluruh siswa mengerjakan soal dengan tenang dan mengumpulkan lembar jawaban tepat pada waktunya.

Berdasarkan hasil observasi, aktivitas siswa di kelas XI IPS 2 sebagai kelas kontrol dapat dikondisikan dengan baik. Siswa juga dapat mengikuti setiap arahan yang disampaikan oleh peneliti, namun antusias siswa dalam mengikuti pembelajaran sosiologi dirasakan masih kurang, hal ini ditunjukkan pada saat peneliti memberikan kesempatan kepada siswa untuk bertanya, hanya ada beberapa siswa saja yang terlihat aktif bertanya dan memberikan argumen sedangkan siswa lainnya belum 
termotivasi untuk ikut aktif terlibat dalam kegiatan belajar.

Berdasarkan hasil uji hipotesis, hasil belajar siswa di kelas eksperimen 1 yang menggunakan model pembelajaran Problem Based Learning berbeda dengan hasil belajar siswa di kelas kontrol yang menggunakan model pembelajaran konvensional metode ceramah pada mata pelajaran sosiologi.

Hasil penelitian menunjukkan bahwa pada proses pembelajaran, siswa di kelas eksperimen 1 yang menggunakan model pembelajaran Problem Based Learning memang terlihat aktif dan dapat bekerjasama dengan baik bersama teman-temannya. Kegiatan belajar tidak lagi terpusat pada guru, tugas guru di sini hanya menjadi fasilitator dan motivator kegiatan belajar siswa di dalam kelas. Hal ini sejalan dengan pendapat Arends (dalamSumarji, 2009, hlm. 1) bahwa model pembelajaran Problem Based Learning (berbasis masalah) adalah suatu proses pembelajaran terkonstruksi bukan proses menerima (receptive process), yang dipengaruhi oleh faktor internal aksi sosial dan sifat kontekstual dari pembelajaran. Model pembelajaran Problem Based Learning telah sukses membuat kegiatan belajar tidak lagi monoton. Antusiasme para siswa dalam mengikuti kegiatan belajar cukup tinggi. Berbeda halnya dengan kelas kontrol yang menggunakan model pembelajaran konvensional metode ceramah. Kegiatan belajar hanya terpusat pada guru, di mana seluruh aktivitas di kelas berada di bawah kendali guru. Siswa hanya mendengarkan dan mencatat apa yang ia lihat dan ia dengar. Hal ini menyebabkan siswa kurang termotivasi untuk lebih aktif saat kegiatan belajar berlangsung.

Berdasarkan hasil penelitian yang telah dilakukan, hasil belajar siswa yang menggunakan model pembelajaran Problem Based Learning berbeda tipis dengan hasil belajar siswa yang menggunakan model pembelajaran konvensional dengan metode ceramah. Hasil belajar siswa di kelas kontrol lebih tinggi dibandingkan dengan hasil belajar siswa di kelas eksperimen 1. Hal ini terjadi karena kelas kontrol merupakan kelas yang paling unggul diantara tiga kelas XI IPS yang ada di SMA Negeri 14 Bandung.

Hasil penelitian menunjukkan bahwa model pembelajaran kooperatif Group Investigation (Gl) mengharuskan siswa untuk dapat ikut berpartisipasi aktif dalam kegiatan belajar. Model pembelajaran kooperatif Group Investigation (Gl) merupakan salah satu model pembelajaran yang menuntut siswa untuk belajar mandiri, karena siswa diberikan kesempatan untuk mencari penyelesaian dari masalah yang ditugaskan dengan cara melakukan investigasi bersama teman sekelompoknya. Tugas guru di sini adalah hanya menjadi fasilitator dan memantau kegiatan siswa selama melaksanakan tugasnya. Tujuan dari model pembelajaran kooperatif Group Investigation adalah agar siswa dapat lebih aktif, kreatif, dan melatih siswa untuk berani berargumen di depan muka umum. Namun fakta di lapangan menunjukkan bahwa antusiasme siswa di kelas eksperimen 2 dalam mengikuti mata pelajaran sosiologi dengan menggunakan model pembelajaran kooperatif Group Investigation masih sangatlah kurang. Hal ini disebabkan 
oleh karakteristik siswa yang tidak dapat dikumpulkan menjadi satu. Kurangnya keakraban antar siswa menyebabkan sulitnya dalam pembagian kelompok, sehingga kerjasama yang baik antar anggota kelompok tidak terjalin.

Berdasarkan hasil penelitian yang telah dilakukan, hasil belajar siswa di kelas eksperimen 2 yang menggunakan model pembelajaran kooperatif Group Investigation (GI) lebih rendah dibandingkan dengan hasil belajar siswa di kelas kontrol yang menggunakan model pembelajaran konvensional metode ceramah. Hal ini terjadi karena pelaksanaan model pembelajaran kooperatif Group Investigation (Gl) di kelas eksperimen 2 kurang persiapan yang matang serta rendahnya antusiasme siswa saat mengerjakan tugas-tugas yang mendukung pelaksanaan model pembelajaran kooperatif Group Investigation (Gl).

Dilihat dari hasil pre test dan post test, hasil belajar siswa di kelas eksperimen 1 mengalami peningkatan, sedangkan hasil belajar siswa di kelas eksperimen 2 tidak mengalami peningkatan. Apabila dibandingkan maka tentu saja hasil belajar siswa di kelas eksperimen 1 yang menggunakan model pembelajaran Problem Based Learning (PBL) lebih baik dibandingkan hasil belajar siswa di kelas eksperimen 2 yang menggunakan model pembelajaran kooperatif Group Investigation (Gl). Hal ini diperkuat oleh penelitian Albanese \& Mitchell (dalam Dzulfikar, A, dkk., 2012, hlm. 3), menunjukkan bahwa, "PBL students scored higher in problem solving".

Ada beberapa alasan perbedaan hasil belajar yang diperoleh dari kedua kelas eksperimen tersebut, diantaranya adalah perbedaan karateristik yang dimiliki oleh masing-masing kelas eksperimen, kondisi kelas, dan waktu belajar yang turut memengaruhi hasil belajar siswa. Minat belajar siswa dari kedua kelas eksperimen saat mengikuti kegiatan belajar pasti berbeda. Ada siswa yang memiliki minat belajar yang tinggi terhadap mata pelajaran sosiologi, adapula siswa yang memiliki minat belajar yang rendah. Namun sebenarnya minat belajar yang rendah dapat diatasi apabila guru dapat lebih memotivasi siswa agar terpacu untuk lebih giat dalam belajar. Selain itu kondisi kelas serta waktu belajar yang tepat juga turut berpengaruh terhadap hasil belajar siswa. Kondisi kelas yang nyaman dan tenang tentu saja akan membuat siswa lebih berkonsentrasi dalam menyerap pelajaran. Dalam hal ini dibutuhkan kerjasama antara siswa dengan guru agar tercipta suasana kelas yang nyaman. Selain kondisi kelas yang nyaman, dibutuhkan pula waktu belajar tepat, karena berdasarkan hasil penelitian siswa di kelas eksperimen 1 yang menggunakan model pembelajaran Problem Based Learning dijadwalkan belajar sosiologi pada jam pertama, yaitu pada pagi hari lebih berkonsentrasi dalam mengikuti kegiatan belajar. Berbeda halnya dengan siswa di kelas eksperimen 2 yang menggunakan model pembelajaran kooperatif Group Investigation (GI), di mana mata pelajaran sosiologi dijadwalkan pada siang hari, sehingga hal tersebut membuat siswa kurang siap dan tidak fokus dalam mengikuti pembelajaran sosiologi dan berakibat pada rendahnya hasil belajar siswa. Oleh karena itu, sudah menjadi tugas seorang guru 
untuk selalu mengawasi dan memberikan motivasi kepada para siswa agar siswa dapat lebih aktif dan kreatif dalam mengikuti kegiatan belajar untuk mencapai hasil belajar yang maksimal.

Berdasarkan hasil penelitian menunjukkan bahwa terdapat perbedaan hasil belajar siswa yang menggunakan model pembelajaran Problem Based Learning (PBL) dengan hasil belajar siswa yang menggunakan model pembelajaran kooperatif Group Investigation (Gl) pada mata pelajaran sosiologi di SMA Negeri 14 Bandung. Hal ini dapat dilihat dari hasil belajar siswa di kelas eksperimen 1 yang menggunakan model pembelajaran Problem Based Learning lebih tinggi dibandingkan dengan hasil belajar siswa di kelas eksperimen 2 yang menggunakan model pembelajaran kooperatif Group Investigation (Gl). Oleh sebab itu dapat disimpulkan bahwa model pembelajaran Problem Based Learning lebih tepat dan efektif digunakan pada mata pelajaran sosiologi khususnya pada pokok bahasan kelompok sosial dibandingkan dengan model pembelajaran kooperatif Group Investigation (GI).

\section{SIMPULAN}

Berdasarkan hasil penelitian dan pembahasan yang telah dikemukakan pada bab sebelumnya, maka dapat disimpulkan bahwa Terdapat Perbedaan Hasil Belajar. Adapun simpulan khusus dari penelitian ini adalah sebagai berikut:

1. Terdapat perbedaan hasil belajar antara kelas eksperimen satu yang menggunakan model pembelajaran Problem Based Learning dengan hasil belajar kelas kontrol yang menggunakan model pembelajaran konvensional. Hal ini dapat dibuktikan melalui hasil perhitungan uji hipotesis yang menyatakan bahwa hasil belajar siswa di kelas kontrol yang menggunakan model pembelajaran konvensional lebih tinggi dibandingkan dengan hasil belajar siswa yang menggunakan model pembelajaran Problem Based Learning (PBL).

2. Terdapat perbedaan hasil belajar antara kelas eksperimen dua yang menggunakan model pembelajaran kooperatif Group Investigation dengan hasil belajar kelas kontrol yang menggunakan model pembelajaran konvensional

3. Terdapat perbedaan hasil belajar kelas eksperimen satu yang menggunakan model pembelajaran Problem Based Learning dengan hasil belajar kelas eksperimen dua yang menggunakan model pembelajaran model pembelajaran kooperatif Group Investigation (GI).

Oleh sebab itu dapat disimpulkan bahwa model pembelajaran Problem Based Learning lebih tepat dan efektif digunakan pada mata pelajaran sosiologi khususnya pada pokok bahasan kelompok sosial dibandingkan dengan model pembelajaran kooperatif Group Investigation (Gl)

\section{DAFTAR RUJUKAN}

Adawiyah, R. (2011). "Penerapan Model Pembelajaran Problem Based Learning (PBL) Untuk Meningkatkan Aktivitas Belajar Siswa". Jurnal Jurusan Pendidikan IImu Pengetahuan Sosial, Fakultas IImu Tarbiyah Dan Keguruan, Universitas 
Islam Negeri Syarif Hidayatullah, Indonesia.

Adinata, F. (2013). "Efektivitas Model Pembelajaran Group Investigation Untuk Meningkatkan Hasil Belajar Siswa Pada Mata Pelajaran Ekonomi". Jurnal Jurusan Pendidikan Ekonomi, Fakultas Keguruan Dan IImu Pendidikan Universitas Tanjungpura Pontianak, Indonesia.

Anita, dkk,. (2013). "Pengaruh Model Pembelajaran Kooperatif Tipe Group Investigation (GI) Terhadap Self-Efficacy Siswa". Jurnal Jurusan Pendidikan Sains dan Program Pascasarjana, Universitas Pendidikan Ganesha Singaraja, Indonesia. 